\title{
AGRICULTURE, GRAZING AND LAND USE CHANGES AT THE SERRA DE TRAMUNTANA KARSTIC MOUNTAINS
}

\author{
Ángel Ginés
}

\begin{abstract}
Karst landforms are one of the most outstanding characteristics of the Serra de Tramuntana range on the island of Mallorca, especially regarding traditional farming and the landscape wilderness. Good examples of polje-like depressions, dolines, karstic gorges and karrenfields are widely distributed over the mountain range. Owing to karrenfields occupying a large surface area in the Serra to the exclusion of arable land, the traditional activity based on the repetitive burning of the Ampelodesmos mauritanica brushwoods for cattle-raising promotes hastening deforestation and soil removal.
\end{abstract}

KEY WORDS: traditional farming, deforestation, agriculture on-karst, livestock on-karst, Mediterranean karst

\section{Introduction}

Karst is probably the most significant factor regarding land use and traditional farming in the Serra de Tramuntana range of Mallorca. About $65 \%$ of the mountains are built of limestone outcrops and many of them show the effects of karstification. Scarcity of water and soil resources have over centuries conditioned the human settlements. Rugged terrains have become a harsh restriction to cattle-raising. The difficult pathways climbing over the steep rocky slopes, as well as the prevailing large estates existing in the Serra, have promoted a kind of self-sufficient rural exploitation called possessions. On the whole, the current landscape of the Serra de Tramuntana is the result of a mixture of karstic wilderness and humanized features such as terraces, cultivated areas and farmhouses, whose economical upkeep is nowadays uncertain.

Basic literature available on Serra de Tramuntana is scarce, but some general overviews can be found in Barceló (1973), Ginés et al. (1979), Promomallorca (1991), Grimalt \& Rodríguez-Perea (1991), GOB (1998) and GEM (1998). More detailed information on several topics is contained in several monographs and specialized papers: Fallot (1922), Gelabert et al. (1992) and Gelabert (1998) on geology and tectonics; Bär et al. (1986). Ginés \& Ginés (1995) and Ginés (1990, 1995) on karst geomorphology; Bolòs \& Molinier (1958) and Bolòs (1996) on vegetation and phytosociology; Waldren (1982) on archeology; Bisson (1977), Grimalt et al. (1992) and Salvà (1993) on human and agricultural aspects; and Equip Tramuntana (1988) on country planning. 


\section{Geological and physical setting}

The Serra de Tramuntana range is the main mountain area on the island of Mallorca (Fig. 1). Over a length of $90 \mathrm{~km}$ and a width of $15 \mathrm{~km}$, this chain lies on the north-west border of the island and occupies a surface area of approximately $1000 \mathrm{~km}^{2}$. It is aligned NE-SW, following the structures of the Balearic Promontory that are the prolongation of the Betic chains. The highest summit is called Puig Major (1445 metres in altitude), but the mountains exceeding 1000 metres number at least fourteen. Owing to the geometry of the thrust system imbrications, the slopes are steep towards the coast but a high energy relief is the common trend all over the Serra. Nearly a third of the total area exhibits a $20 \%$ gradient or more, which renders such terrain unsuitable for agricultural exploitation.

The structure of the Serra de Tramuntana is the result of Alpine compressive events occurred between Late Oligocene and Middle Miocene (Gelabert et al., 1992). The existence of a NW-directed fold and thrust system is the most outstanding characteristic. Thrusts are gently dipping to the southeast and the piles of thrust sheets are imbricated for several hundred meters in thickness on the central part of the Serra, striking NE-SW. Due to the sheet imbrications, the topographic recurrence of limestones and shale and marly rocks creates a distinctive sawtooth relief. Extensional faults, active since the Late Miocene, account for the boundaries of the mountain range.

Triassic, Jurassic and Miocene rocks constitute more than $80 \%$ of the outcrops in the Serra de Tramuntana area. Quaternary deposits, such as screes, colluvium and some alluvial sediments form almost $10 \%$ of the total surface. The stratigraphic column (Fig. 1) involves rocks from Upper Paleozoic to Middle Miocene in a complex sedimentary record stopped by the emplacement of the thrust events. The compressional structures are sealed by flat-lying sediments from Serravallian to Quaternary.

The main outcropping rocks are the Triassic deposits (marls, shales, sandstones, volcanic rocks, gypsum and some carbonate rocks), the Jurassic limestones (Lower Lias) and the preorogenic Miocene rocks (conglomerates, calcarenites and marls). Karst landscapes are strongly developed on Jurassic micritic limestones, both massives and brecciated, but also on Miocene carbonate rocks. Triassic soft materials are frequently found in the floor of the major karstic depressions or as valley bottoms, but they are more widely exposed in the terraced slopes at the foot of mountains. In many places Triassic and Lower Jurassic rocks uncomformably overlay the Miocene deposits because the Triassic Keuper acts as decollement levels.

Rainfall values are relatively high, surpassing $1200 \mathrm{~mm}$ in the central area of the range. Intense rainfall events with over $250 \mathrm{~mm}$ in 24 hours are reported having a recurrence interval of 25 years. Mean temperatures are also high, but differs very much along the altitude gradients: from $13^{\circ} \mathrm{C}$ in the central part (around Lluc) to $17^{\circ} \mathrm{C}$ in the outermost Formentor and Andratx areas. Winter mean temperatures of roughly $6^{\circ} \mathrm{C}$ as well as summer means close to $25^{\circ} \mathrm{C}$ are common values. Snowfalls 


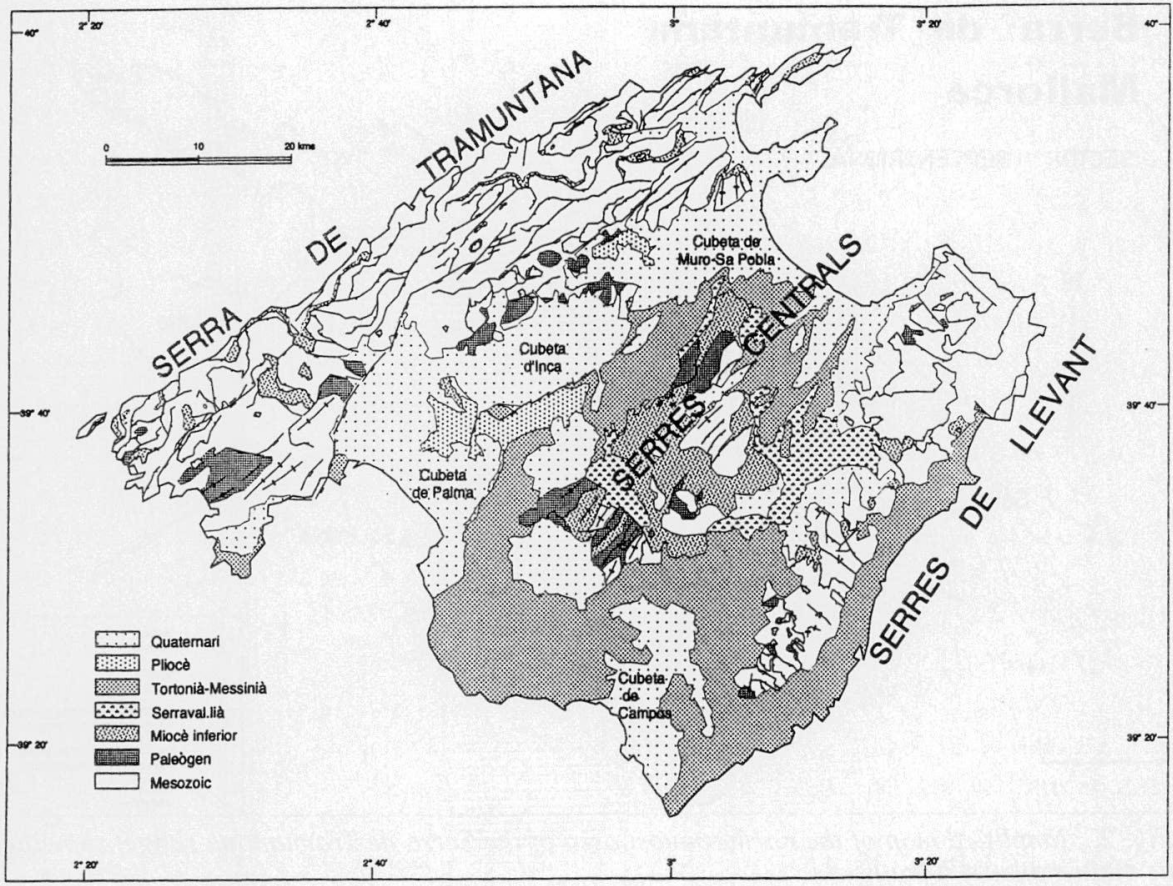

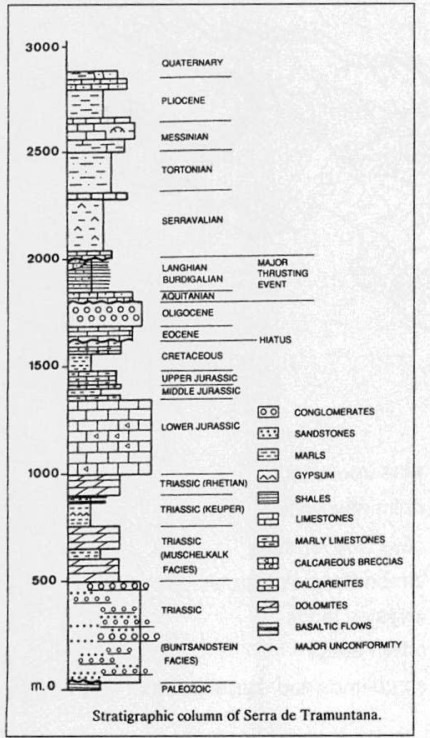

Fig. 1. Summarized geological map and stratigraphic column of Mallorca. are rare but their occurrence is recorded several times each year in the highest summits. As a whole, the Serra de Tramuntana range has a typical Mediterranean climate, spanning from humid to semiarid subtypes along the topographical gradients.

\section{Karstic landforms, terraces and agriculture}

Specific karstic features can be recognized, particularly in the northern sector of the range (Fig. 2), conditioning the availability of soil for pastures and crops. Several kinds of karrenfields are used for stockbreeding, from the top of the mountains to sea level. Karstic depressions are the best lands for wheat, barley and other cereal crops. But the olive tree bearing man-made terraces (called marjades) and the almond tree plantations (Fig. 3) are related with unkarstifiable rocks, mainly colluvial deposits, marls and shales. Forestry resources are limited to Aleppo pines at lower elevations and dense woods of sclerophyllous holm oak, which define the treeline rou- 


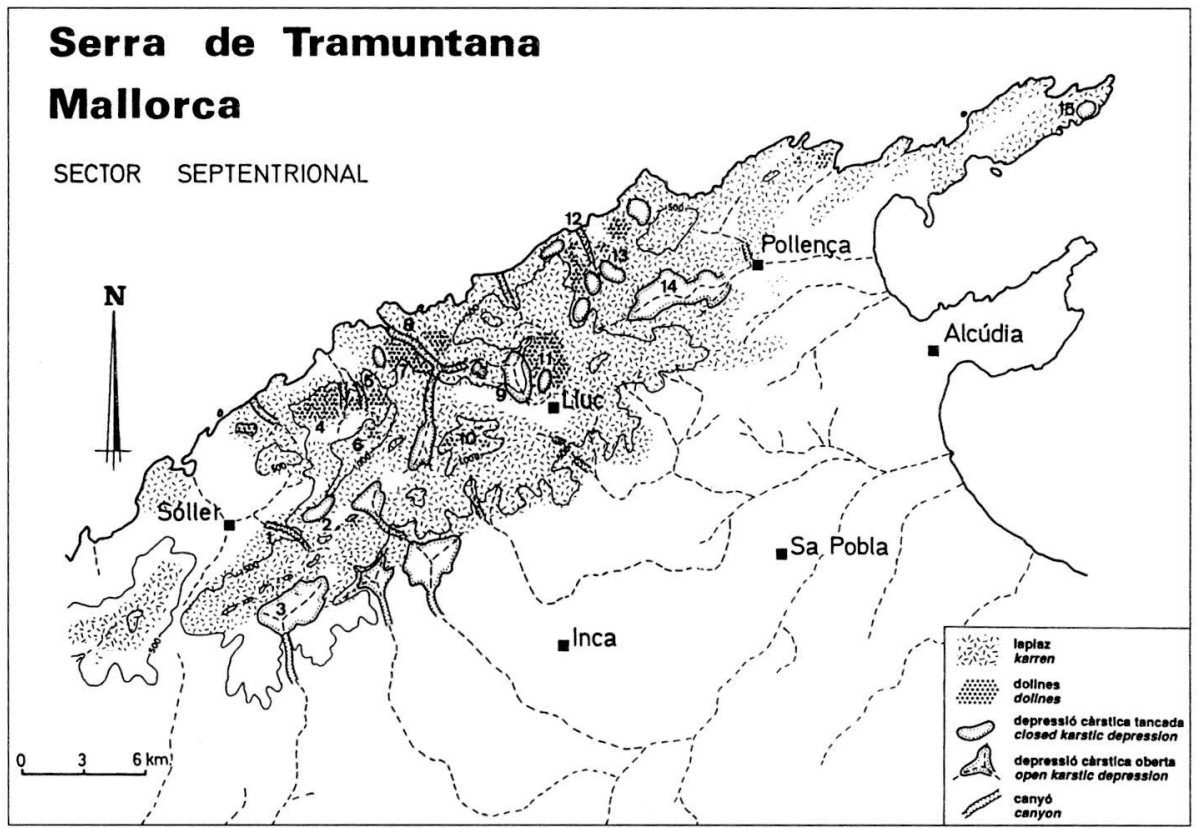

Fig. 2. Simplified map of the northernmost area of the Serra de Tramuntana range, showing its main exokarstic features.

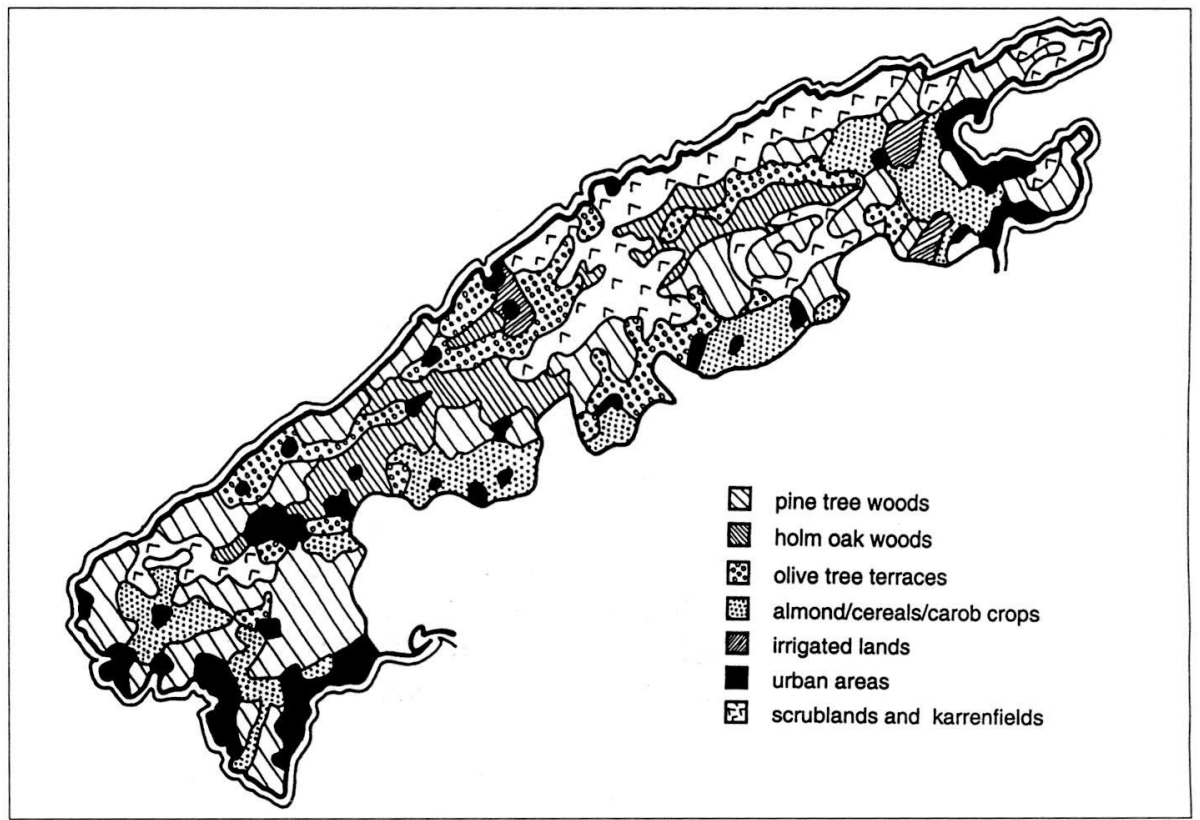

Fig. 3. Agricultural and vegetational cover of the Serra de Tramuntana. Terraced surfaces devoted to olive and almond crops correspond to unkarstifiable rock terrains. 
ghly over 800 metres in altitude. The karstified top of the mountains holds the so-called "balearic zone", where a remarkable richness in endemic species can be found. Uncultivated lands form garrigue and thorny cushion scrublands, both on limestone and on marly rocks.

The most characteristic features of the landscape in the Serra de Tramuntana are closely related to lithology. Relief features and vegetation show their dependence on rock substrates, remarkably emphasized in the field by the tectonic trends that cause imbrication of different materials over long distances. Human intervention is also different on marly rocks and colluvial deposits when compared with the restricted land uses developed on hard limestones, lacking in soil cover and frequently consisting of inaccessible ground. Lower slopes, soft substrates and deeper soils encourage the terracing of the hillsides by man. The terraces are constructed across the slope and the earth is supported by elaborate walls, whose skilfully laid and exceptionally close fitting stonework is built without mortar.

Terracing extends over large areas in the Serra, but rarely prevails over karstic grounds. Grimalt et al. (1992) estimates at 16765 hectares the total surface of terraced areas, which means nearly a half of the cultivated land and more than $10 \%$ of the total area of the Serra de Tramuntana range. Only $8.7 \%$ of the limestone outcrops has been subjected to terracing. Therefore, it implies that just a relatively small overlap of karstic features and artificial terraces exist, a fact easy to recognize in the landscape.

Exokarstic landforms are quite a common feature in the Serra de Tramuntana mountains, owing to the presence of extensive limestone outcrops as well as to the suitable bioclimatic environment that promotes the development of karst processes. Good examples of polje-like depressions, dolines, karrenfields and karstic gorges can be found, especially in the northern part of the range. Karrenfields are the most remarkable ones because of their morphological variety and wide occurrence. Besides the geomorphological significance of exokarstic landforms, the landscape of the Serra is strongly affected by a great array of solutional features.

Great karstic depressions are concave forms, similar to poljes, consisting of wide flat floored areas whose dimensions rarely exceed two kilometers in length. Many of them are not in fact closed depressions because they are drained by streams or karstic gorges. Their morphology is, in most cases, conditioned by the structural directions which are dominant in the mountain range as well as by the thrusting that puts into elongated contact soft marly rocks with limestone outcrops. The traditional farming chose these broad karstic depression to grow cereals, namely xeixa wheat in the upper depressions like Coma de Son Torrella. Dolines are frequent karstic features on a few areas sited in the intensively karstified sectors of Escorca, although they are less significant in the landscape than karrenfields. They form scattered groups and consist of medium sized depressions characterized by oval or subcircular perimeter that can enclose small surfaces, from 200 to $15000 \mathrm{~m}^{2}$, thus corresponding to major axis lengths between 20 and 150 metres. These dolines feature a rather flat floor 
occupied by silty soil (Fig. 4) where a particular fire-controlled plant community grows, dominated by heather, Erica arborea. The total surface area of dolines is negligible with respect to the surrounding karrenfields.

Karren features spread over large extensions of limestones, lacking a soil covering, to form large-sized karrenfields. These rocky assemblages are important absorptional megaforms that can occupy up to several $\mathrm{km}^{2}$. If the karrenfield evolution takes place for long, the dissolution progress gives rise to almost impassable terrain, interrupted by sharp ridges and spectacular pinnacles recalling some tropical karren landforms. The most impressive karrenfields are located on the NW slope of the northern sector of the Serra, between Sóller and Pollença, at rather moderate elevations (from 200 to 600 metres a.s.l.). Any kind of cultivation is hampered by such karrenfield outcrops.

Intensely karstified terrains are not suitable for agriculture. Karrenfields, steep slopes, cliffs, deep gorges and rocky surfaces hinder most farming activities. Only grazing by sheep and goats on the gentler karrenfields and cereal cultivation on the bottom of karstic depressions can be implemented, but always with severe restrictions.

\section{Karrenfields, deforestation and grazing}

As a general rule human activity tends to simplify the initial complexity of the ecosystems and tends to upset the bioclimatic equilibrium conditions that control the

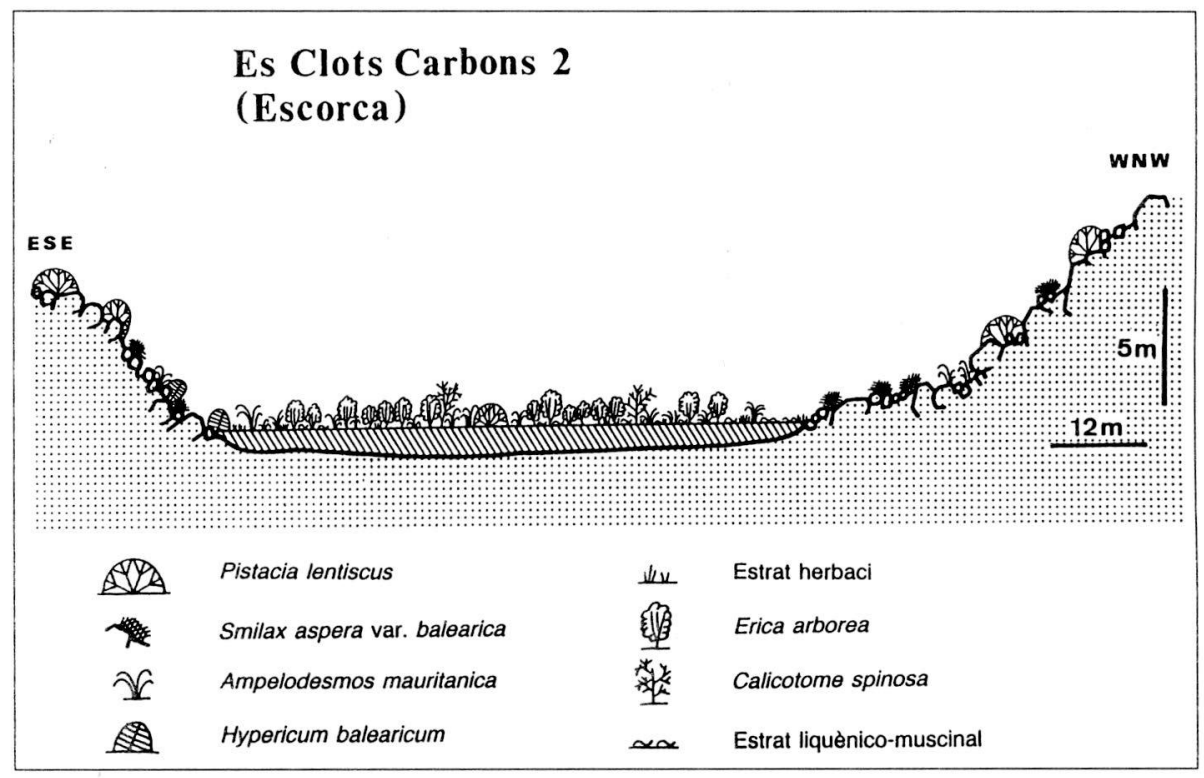

Fig. 4. Profile drawing of a typical doline affected by repetitive fire for cattle-raising. 
action of the main agents and geomorphological factors. Human settlement in Mallorca, a little more than 7,000 years ago, necessarily brought about changes both in the plant cover and in the predominant erosion mechanisms.

It is likely that during the first four millennia, human activity had few ecological consequences. But the men of different cultures who subsequently inhabited the island produced important cattle-raising and farming changes, so causing the regression of the steady-state forests of Quercus ilex and also of the more termophile ones of Pinus halepensis. The Roman colonization commenced in $123 \mathrm{BC}$, but the greatest agricultural changes in Mallorca took place during the Muslim epoch, between the 9 th and the 13 th centuries.

Since the Catalan conquest of Mallorca by King Jaume I d'Aragó in 1229, the mountain territories were divided between a small number of important landowning nobility. Through the centuries, until the remarkable shift in economics produced by tourism, the traditional farming over such large estates (possessions) were based on livestock, cereal crops, olive oil production and forestry. Firewood, timber and charcoal supplies caused the regression of the forests, but land reclaimed for cultivation especially, greatly modified the wild vegetation over centuries.

Because karrenfields occupy a large amount of surface in the Serra, and excluding arable land, cattle-raising has remained the major rural activity able to be developed on such generally unforested terrain. Woodfires have historically been the main cause of the plant cover decay in the karst landscape of Mallorca. To the former deforestation, due to the development of larger agricultural areas, must be added the deeply rooted habit of periodically burning the brushwood in order to renew the grazing lands.

The traditional activity based on the repetitive burning of herbaceous brushwoods of càrritx, (Ampelodesmos mauritanica) for cattle pasturing, has become the most influential human activity that affects the broad karrenfields of the Serra de Tramuntana range. The active soil removal produced after the deforestation and the progressive degradation of scrub formations, leads to a gradual increase of the bedrock surface exposed to the atmosphere. Because the most conspicuous karren landforms can be found on rocky outcrops on which the soil cover is less than $50 \%$, obviously deforestation and soil removal enhance the spreading of karrenfield surfaces.

All along the Serra altitude range, from 0 to 1445 metres a.s.1., relict features of rounded subcutaneous karren are common. At the same time, progressive transformation of subsoil-generated tubes and hollows which are actively reshaped into typical bare karren features, is observed. Because the soil formation rate is very low in the karrenfields of Mallorca, any disturbance which facilitates an increase of the soil removal rate might provoke an irreversible imbalance. Forest destruction and the ready removal of small soil particles, all along the hillsides and also through karstified fissures, can be monitored with the aid of small-scale subsoil karren features (Ginés, 1995). 


\section{Recent land use trends}

Some changes in agricultural land use in the Serra de Tramuntana over the 19th and 20th centuries have been documented (Fig. 5), namely the expansion of almond trees on the southern hillsides and a gentle recession of olive tree terraced-plantations (GEM, 1998). But the most significant switch occurred after the fifties, due to the increasing economic and social impact of tourism in Mallorca.

Mechanization of farming was very difficult and the traditional possessions became inefficient in economic terms. Furthermore the availability of rural manpower was completely blocked because wages became too expensive for the landowners. During the 19th century, $80 \%$ of the working population in the Serra was devoted to rural activities but this percentage has fallen dramatically and hardly reached $12 \%$ in 1990. At present, in economic terms, the service sector accounts for $75 \%$ of the Gross Domestic Product of the Serra, whereas less than $4 \%$ only belongs to agriculture
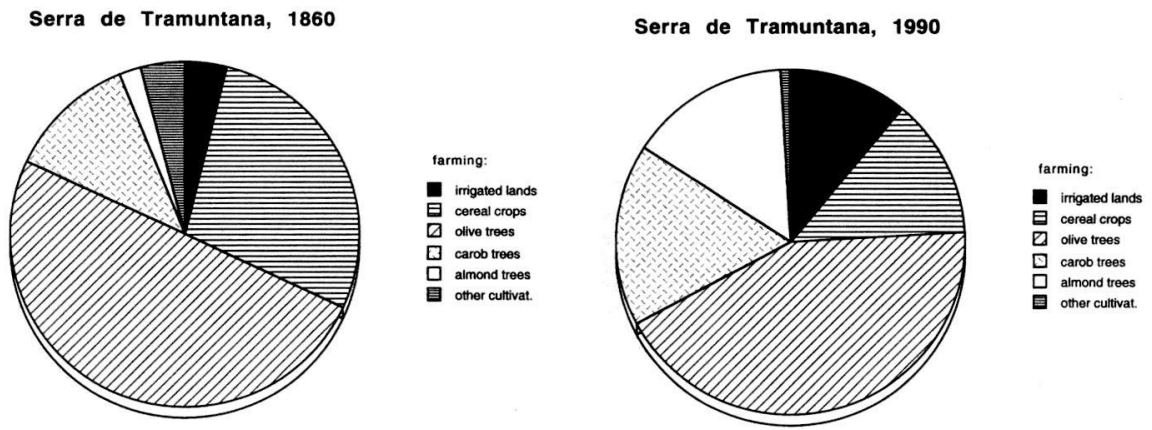

Fig. 5. Changes in agricultural land use over the 19th and 20th centuries.

(GOB, 1998). The current increase of abandoned terraces and decreased cultivation is now clear evidence of this collapse of traditional farming.

Wild or spontaneous vegetation occupied $19 \%$ of the recognized terraces from the data collected by Grimalt et al. (1992) from aerial photographs obtained in 1979. The decrease in terraced land surfaces has been reported during the second half of the 20th century through statistical data and aerial photographs from Deià and Fornalutx municipalities (Fig. 6). After being abandoned, the terraces are affected by degradation processes produced by wall collapse and subsequent erosion, which leads in some cases to a progressive advance of the closer forest communities. Frequently also, abandoned terraces can be transformed into unforested slopes when periodic fire-raisings accelerate the destruction of the terraces and inhibit the forest recovery, favouring the growth of a monotonous grassland of càrritx, Ampelodesmos mauritanica.

Karrenfields and dolines are also subjected to the effects of periodical burning of 


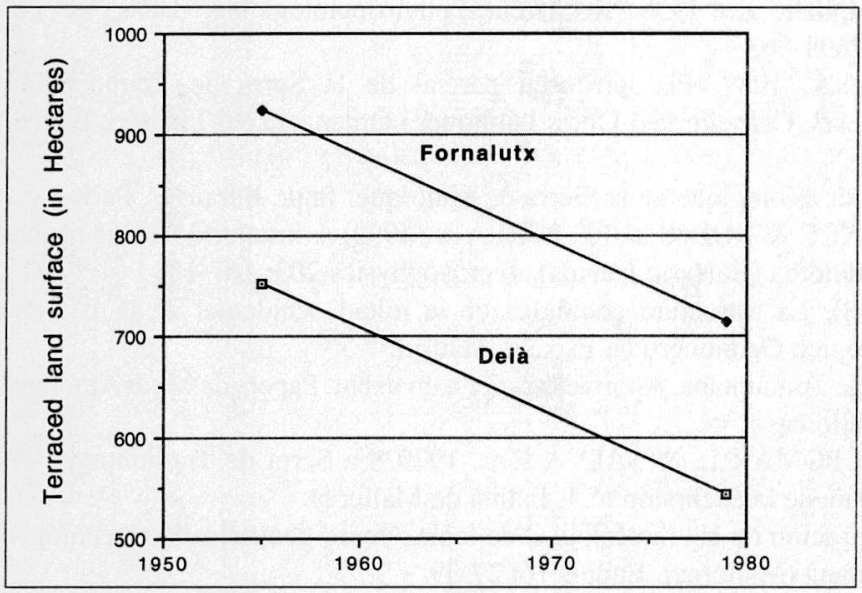

Fig. 6. Recent changes documented on the terraced lands of Deià and Fornalutx municipalities.

càrritx clumps for the renewal of cattle-rising pastures. Degradation of plant communities and soil removal threaten the sustainable exploitation of livestock and at the same time cause environmental problems concerning the protection of endemic species and outstanding wild plant associations. Many karrenfield landscapes in the Serra display several stages of regressive succession owing to the impoverishment of the vegetational cover that follows recurrent fire-raisings.

The sudden changes introduced by tourism in Mallorca after 1950 led to the crisis of the traditional farming, but in the beginning the direct impact of tourism on the Serra was limited to a few overcrowded places visited by coaches, such as Sa Calobra, Formentor and Valldemossa. However, trends in the tourist trade have launched during the last few decades new recreational and residential land uses, like rural urbanization for second homes, agrotourism facilities and outdoor activities related to the exceptional wilderness value of the Serra de Tramuntana. These new changes have potential environmental impacts that must be counteracted by proper land management.

\section{ACKNOWLEDGEMENTS}

The author wishes to thank Warwick Hutchinson for his helpful improvements of the earlier draft of this paper.

\section{REFERENCES}

BÄR W.F., FUCHS F. \& NAGEL G., 1986. Lluc / Sierra Norte (Mallorca). Karst einer Mediterranen Insel mit Alpidischer Struktur. Zeitschrift für Geomorph. N.F. suppl. 59: 27-48.

BARCELÓ B., 1973. Aspectos geográficos de Mallorca. In: MASCARÓ-PASARIUS J.M. (ed.), Historia de Mallorca, Palma de Mallorca, 97-203.

BISSON J., 1977. La terre et l'homme aux îles Baléares. Édisud, Aix-en-Provence, 431 pp.

BOLÒS O., 1996. La vegetació de les Illes Balears. Institut d’Estudis Catalans, Barcelona, $267 \mathrm{pp}$. 
BOLÒS O. \& MOLINIER R., 1958. Recherches phytosociologiques dans 1'île de Majorque. Collect. Bot. 5: 699-863.

EQUIP TRAMUNTANA, 1988. Pla territorial parcial de la Serra de Tramuntana. Universitat de les Illes Balears, Conselleria d’Obres Públiques i Ordenació del Territori, Palma de Mallorca.

FALLOT P., 1922. Étude géologique de la Sierra de Majorque. Impr. Béranger, Paris.

GELABERT B., SÀBAT F. \& RODRÍGUEZ-PEREA A., 1992. A structural outline of the Serra de Tramuntana of Mallorca (Balearic Islands). Tectonophysics 203: 167-183.

GELABERT, B. (1998). La estructura geológica de la mitad occidental de la Isla de Mallorca. Instituto Tecnológico Geominero de España, Madrid.

GEM, 1998. La Serra de Tramuntana. Aportacions per a un debat. Papers de Medi Ambient 3, Sa Nostra, Palma de Mallorca.

GINÉS A., GINÉS J., POMAR L. \& SALVÀ P.A., 1979. La Serra de Tramuntana, VI Coloquio de Geografía, Guía de la excursión no 1, Palma de Mallorca.

GINÉS A., 1990. Utilización de las morfologías de lapiaz como geoindicadores ecológicos en la Serra de Tramuntana (Mallorca). Endins 16: 27-39.

GINÉS A., 1995. Deforestation and karren development in Majorca, Spain. In: BÁRÁNYKEVEI I. (ed.), Environmental effects on Karst terrains, Homage to László Jakucs, University of Szeged: 25-32.

GINÉS A. \& GINÉS J., 1995. Les formes exocàrstiques de l'illa de Mallorca / The exokarstic landforms of Mallorca island. Endins 20: 59-70.

GOB, 1998. La Serra de Tramuntana, natura i cultura. Editorial Moll, Palma de Mallorca.

GRIMALT M., BLÁZQUEZ M. \& RODRÍGUEZ R., 1992. Physical factors, distribution and present land-use of terraces in the Tramuntana mountain range. Pirineos 139: 15-25.

GRIMALT M. \& RODRÍGUEZ-PEREAA. (eds.), 1991. Libro-Guía de las excursiones de las VII Jornadas de Campo de Geografía Física. Universitat de les Illes Balears, Palma de Mallorca.

PROMOMALLORCA, 1991. Mallorca. Serra de Tramuntana. Promomallorca Edicions SA, Palma de Mallorca.

SALVÀ P., 1993. Changes and perspectives in agricultural land-use and their geoecological consequences on the mountains of Mallorca island. Pirineos 141-142: 85-96.

WALDREN W., 1982. Balearic Prehistoric Ecology and Culture. British Archaeological Report, 149, Oxford. 